\title{
O tajemniczej staropolskiej potrawie - giejślic (siódma woda po kisielu?)
}

Słowa kluczowe: historia języka, język staropolski, prasłowiańszczyzna, leksyka kulinarna, etymologia.

doi: http://dx.doi.org/10.31286/JP.101.4.5

W Słowniku staropolskim odnajdujemy tajemniczy wyraz z zakresu kulinariów, mianowicie giejślic. Słownik podaje następujące znaczenie: 'kisiel lub żur, ius acidulum e farina confectum vel farina cum melle mixta ac fermentata', tj. posiłek kwaśny lub podany z miodem i sfermentowany. W Materiałach źródłowych do słownictwa przyrodniczego średnich wieków $w$ Polsce Józefa Rostafińskiego odnajdujemy pierwsze poświadczenie jednostki z 1472 roku: Zur, geyslicz glycerium. Słownik pojęciowy języka staropolskiego opatruje hasło komentarzem: „Wyraz być może niemiecki”. Podobną informację odnajdujemy w sstpKart. Oprócz niemieckiej genezy wyrazu podano tam uściślenie jego znaczenia: geyslicz = glicerium 'polewka z zakwaszonych otrąb żyta, inaczej żur'; niem. geislitz, giselitz, giselitze, gislitz.

W czasie analizy tej jednostki pojawiają się jednak co najmniej trzy niewiadome: czym był giejślic, co to za potrawa staropolska, następnie jaka jest etymologia tego wyrazu w polszczyźnie, a jeśli to wyraz zapożyczony z niemieckiego, jakimi drogami został przejęty do polszczyzny z języka skądinąd wyraźnie wpływającego na staropolszczyznę w zakresie kulinariów; na koniec, czy giejślic, żur i kisiel to rzeczywiście tożsame potrawy, skoro sstp po takie synonimiczne definicje sięga, czy tylko zbliżone ze względu na typ wykorzystanych produktów, specyfikę dań czy sposób ich przyrządzania. Postaram się przyjrzeć tym problemom, sięgając zwłaszcza do dużo bogatszej literatury niemieckiej na ten temat, w tym do najstarszych źródeł właściwych w języku niemieckim dla tego pola semantycznego, czyli książek kucharskich.

W słownikach języka polskiego odnajdujemy niewiele poświadczeń tego wyrazu. Notują go jedynie sstp, SPXVI (który w zasadzie podaje informacje dotyczące giejślica za sstp; warto dodać, że tego leksemu nie odnajdujemy w SPXVIKart ani w Korpusie polszczyzny XVI w.) oraz Cn. Jednostkę tę wymienia także Tomasz Czarnecki w monografii Die deutschen Lehnwörter im Polnischen. Untersuchungen zur Chronologie und Geographie der Entlehnungen. Autor odnotowuje zaledwie: Giejślic (1472) < mhd. ${ }^{1}$ Gîslitz (II). Przypisuje tę nazwę do drugiego etapu przyjmowania pożyczek niemieckich, tj. między 1050 a 1600 rokiem, oraz przytacza poświadczenie w polszczyźnie z 1472 roku. Określa ten rzeczownik jako średnio-wysoko-niemiecki (Czarnecki 2014: 200), co pozwala przypuszczać, że wyraz ten funkcjonował w języku niemieckim w okresie między 1050 a 1350 rokiem, gdyż badacze właśnie takie granice chronologiczne wyznaczają tej

\footnotetext{
* sylwia.przeczek@uj.edu.pl; ORCID: oooo-0oo2-6734-9560

1 mhd. (mittelhochdeutsch): średnio-wysoko-niemiecki.
} 
historycznej formie języka niemieckiego. Warto w tym miejscu zaznaczyć, że w języku średnio-wysoko-niemieckim występowała forma z -i-: gîslitz, która w regularny sposób uległa dyftongizacji, tzw. dyftongizacji nowo-wysoko-niemieckiej. W jej wyniku długa samogłoska $̂$ przeszła w -ei, stąd geislitz. Następnie formę z dyftongiem przejął język polski: giejślic.

W opracowaniu Augustina Unterforchera z 1899 roku odnajdujemy następującą informację o analizowanym leksemie: „J. 1511. mhd. gîselitze, gîslitz, cech. ${ }^{2}$ kiselice, kwaśna owsianka w Kals"3 (1899: 21).

Poświadczenie zatem już z 1511 roku pozwala nam stwierdzić, że giejślic był kwaśną potrawą z owsa, nazywaną kisielica (Unterforcher: potrawa z owsa, sstpKart: z żyta). Istotą potrawy był z pewnością jej kwaśny smak, na co zwraca uwagę już sstp. Podstawą potrawy było zboże gatunek być może taki, jakiego było akurat pod dostatkiem w danym regionie; zboże to poddawano zakwaszaniu. Autor zaznacza - co istotne - czeskie źródło tego leksemu. Taką samą informację odnajdujemy w Słowniku staroczeskim Jana Gebauera ${ }^{4}$. Podobne spostrzeżenia formułuje Heinz-Dieter Pohl w pracy Deutsch-slowenische Wechselbeziehungen in der Sprache der traditionellen Kärntner Küche. Autor formułuje tezę, że niemieckie gaislitz pochodzi od słowiańskiego ${ }^{\star} k y s e l i c a$ (nieco dalej uściśla: ze słoweńskiego kiselica, na innych terenach z czeskiego kiselice). Było to danie dawne, chłopskie, znane w Dolnej Karyntii (Matthias Lexer podaje bogatą dokumentację na gîseliz, geislitz z Karyntii i Tyrolu i dodaje, że wyraz pochodzi prawdopodobnie ze słowiańskiego, por. czes. kyselice (1872: 1023)) oraz w Tyrolu Wschodnim (Hornung 1964: 79), gdzie nazwa ta brzmiała $g \bar{a} i(z)$ lit $\beta$, a oznaczała 'kwaśną, beztłuszczową owsiankę spożywaną na zimno po zamrożeniu'. Okazuje się, że danie to było podawane już w XII wieku w klasztorze św. Floriana pod Linzem. W XIII-wiecznym poemacie Meier Helmbrecht ogrodnik z obszaru między Wels a Treuenfels otrzymał właśnie to pożywienie: geyslitze. Wspomniane źródła podkreślają związek leksykalno-semantyczny kisielicy z językiem rosyjskim. H.D. Pohl

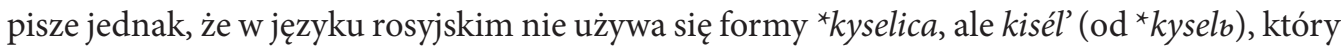
według słownika Władimira Dala jest polewką z owsa, jęczmienia i mąki pszennej, która jest utrzymywana w cieple i zakwaszona (danie udokumentowane już w 997 roku). Autor zrównuje zatem niem. geislitz, słow. kyselica z ros. kisielem. Dodaje ponadto: „Fakt, że słowa (i rzeczy) Tålggen, Munggen i Gaislitz są wyraźnie pochodzenia słowiańskiego, ale nie są już używane przez naszych współczesnych słowiańskich sąsiadów, wydaje się niezwykły " (Pohl 2019: 261). Wnioskuje na tej podstawie, że owies odgrywał bardzo ważną rolę u starożytnych Słowian, a od dawna zachował się u Rosjan (i Finów) na wschodzie oraz Słowian alpejskich na zachodzie, jeszcze zanim w Alpach mówiono po niemiecku. Dlatego formy dźwiękowe tych potraw są bardzo stare ze słowiańskiego punktu widzenia. Te ustalenia dosłownie powtarza H.D. Pohl w pracy Deutsch-slowenische und slowenisch-deutsche Lehnbeziehungen als Spiegel der Kulturgeschichte (gezeigt an Speisenbezeichnungen).

\footnotetext{
2 cech. $=$ čech.

3 Kals w Tyrolu.

4 O przypuszczalnym czeskim rodowodzie leksemu w dalszej części artykułu.

$5 \mathrm{Z}$ tym ostatnim stwierdzeniem autora nie można się zgodzić, słowo kisielica jest używane nadal w języku czeskim oraz w języku polskim w odmianie dialektalnej, o czym szerzej w dalszej części artykułu.
} 
62 | ARTYKUŁY I ROZPRAWY | J̨̨ZYK POLSKI | CI 4

Do wymienionych już w powyższych opracowaniach najstarszych niemieckich notacji wyrazu - okazuje się, że prawdopodobnie ograniczonego terytorialnie i społecznie - jeszcze powrócę, w pierwszej kolejności bowiem przyjrzę się wspomnianej w źródłach niemieckich słowiańskiej nazwie kyselica // kisielica.

Co istotne, sstp nie odnotowuje hasła kisielica, a jedynie kisiel 'potrawa z mąki rozrobionej z wodą i poddanej fermentacji, nie zaznacza jednak, jakiego rodzaju mąki. Odnajdujemy je dopiero w słowniku Lindego, ale z innych języków, nie z polskiego:

s.v. kisać mamy: cf. kwas (Ross. кислиน, berberys, Vind. kiselica, kisleza 'szczaw', Bosn. kisselica 'drożdże' (L I: 359),

zatem z ros. kislica, nie kisielica; natomiast kiselica 'szczaw' ze Styrii (nazwa zatem słoweńska), kisselica ‘drożdże’ z Bośni (zatem serbsko-chorwacka, dziś - bośniacka), w swil:

kisielica, y, lm. e, ż. woda zawierająca w sobie kwas węglowy oraz w SW:

kisielica 1. woda zawierająca kwas węglowy, szczawa, 2. por. kisiałka.

Wspomina o tym leksemie również Franciszek Sławski:

W podobnym znaczeniu od tego samego rdzenia: cz. lud. kyselo 'kwaśna polewka, kapuśniak', stcz. kysĕlicĕ 'kasza przyrządzana na kwaśno', sch. Kiselica 'kwaśna polewka' (SESł, t. 2: 173).

Te notacje odsyłają zatem z kolei do czeszczyzny i do języka serbsko-chorwackiego.

Kisielice odnajdujemy ponadto w SGP PANKart w znaczeniu 'zupa owocowa zaprawiana mąką̧. Istotny zapis pojawia się w SGPKarł: Kisielica a. Kwasza = żur. We wskazanym w SGPKarł źródle czytamy ponadto:

Kwasza v. kisielica = żur. Polewka z różnych części mąki żytniej i hreczanej, zarabianych na gęsto, co następnie rozrzedza się ciepłą wodą i poddaje się kiśnieniu, potem się gotuje, a gdy zawrze, je się na gorąco (Parylak 1877: 70).

Autor powołuje się zresztą na pracę Aleksandra Kremera, w której czytamy:

Kwasza, (r.) rodzaj zupy z równych części mąki żytniej i hreczanej, zarobionych wodą na klajster, co następnie rozrzedza się wodą ciepłą i poddaje lekkiej fermentacji, potem się gotuje, a gdy zawrze, podaje się na gorąco (Kremer 1870: 211).

A. Kremer nie podaje jednak leksemu kisielica (kwaszę zalicza do prowincjonalizmów wschodnich - Kamieńca Podolskiego), co czyni Piotr Parylak, który z kolei, co istotne, wyznacza zasięg terytorialny leksemu i uznaje go również za regionalizm wschodni (dziś tereny Ukrainy).

Dawności leksemu kisielica mogłaby dowodzić nazwa miejscowa Kisielice - miasto w województwie warmińsko-mazurskim, udokumentowane już w XIII wieku (forma Kiszelycz) na terytorium dawnej Pomezanii, czyli obszarze zajętym przez plemiona pruskie w XII wieku. Do 
końca XII stulecia tereny te były jednak zamieszkałe głównie przez plemiona słowiańskie. Według Kazimierza Rymuta nazwa ta jednak (wcześniej niem. Vrienstag, Freystadt) nie ma jednoznacznej etymologii (od n.os. Kisiel + suf.-ice lub od przym. kisly (kisieć 'kisnąć, psł. $\left.{ }^{\star} k y s e ̌ l b\right) ~ c h a r a k t e r y-$ styczny dla terenów nadwodnych; możliwa jest zresztą postać Kisielec notowana przez SG). Co ciekawe również, a dotyczące onomastyki, według badań portalu „Nazwiska polskie” nazwisko Kisielica było niezwykle rzadkie w 2020 roku, w całej Polsce nosiły je zaledwie 32 osoby: 13 na Podkarpaciu, 10 na Dolnym Śląsku i 4 w województwie zachodniopomorskim. Te obszary właśnie - Podkarpacie i Dolny Śląsk - są znaczące w kontekście polskiego leksemu kisielica i jego terytorialnego ograniczenia. Warto w tym miejscu zaznaczyć z kolei, że nazwiska Kisielica nie odnajdujemy w Słowniku najstarszych nazwisk polskich, pojawia się w nim tylko nazwisko Kisiel (KISIEL, KISIE < kisiel 'rodzaj gęstego żuru' sstp 1362, odap. (Kowalik-Kaleta i in. 2007: 66)).

Pozostając w kręgu onomastyki, nie sposób nie wspomnieć, że Kiselica to również wieś w północno-wschodniej Macedonii. Sławski notuje wszakże również serbsko-chorwacki leksem Kiselica 'kwaśna polewka'. Na obszarze południowej Słowiańszczyzny, jak już zaznaczono powyżej, znany jest zresztą i obecnie wyraz kiselica w kilku znaczeniach. W języku bośniackim notuje się aż dziewięć znaczeń, tu podano te wyłącznie kulinarne: 1. 'kwaśna zupa'; 2. 'ciasto gotowane w zalewie z kiszonej kapusty'; 3. 'rodzaj potrawy z mąki pszennej, otrębów i cebuli'; 4. 'dżem śliwkowy'; 5. 'wino kwaśne’; 6. 'wino brandy z osadu drożdżowego' W języku chorwackim kiselica oznacza szczaw i potrawy ze szczawiu - kwaśnej zresztą rośliny.

Współcześnie znane jest również słowo kisielica, a dokładniej kisełycia, oznaczające łemkowską zupę przygotowaną na bazie żuru na zakwasie z razowej mąki owsianej, danie bardzo popularne również na Podkarpaciu. Potrawa ta wpisana została ponadto w 2007 roku na listę produktów tradycyjnych w kategorii "Gotowe dania i potrawy w woj. dolnośląskim”"

Wygląd:

Gęsta polewka z widocznym listkiem bobkowym (laurowym), zielem angielskim, ziarnami czarnego pieprzu oraz kminku.

Konsystencja:

Płynna, gęsta.

Smak:

Smak kwaśny, posmak kminkowo-laurowy, z charakterystycznym aromatem czosnku.

Czytamy ponadto w tym zestawieniu:

Żur łemkowski zwany kysylicią, kisielica lub keselica, [...] swymi korzeniami sięga XvII wieku. [...] Źródła pisane autorstwa Oskara Kolberga [...] Sanocko-Krośnieńskie wymieniają kysitycię jako jedną z głównych potraw, spożywanych przez ubogą rolniczą społeczność łemkowską [...]: W Bóbrce we dworze (czeladź) jedzą rano około siódmej barszcz z mąki żytniej albo z owsianej, który ma nazwę kisielica (kisyłicia) [...] [w Leszczowatem] je się tutaj kisiełycię [czyli] żur owsiany, barszcz żytni lub buraczkowy [...] [w Klimkówce] jedzą zwykle kartofle, kapustę [...], 
64 | ARTYKUŁY I ROZPRAWY | J̨̨ZYK POLSKI | CI 4

kisielnice, czyli żur z owsianej mąki [...] (Oskar Kolberg, Dzieła wszystkie, tom 49, Polskie Towarzystwo Ludoznawcze Wrocław-Poznań, 1974).

[...] Żur łemkowski zwany keselica, kysielnica lub kysyłycią wytwarzany jest w sposób tradycyjny przez Łemków osiadłych w Przemkowie i okolicach, nieprzerwanie od 1947 r. Łemkowie spożywają go podczas świąt wielkanocnych i bożonarodzeniowych, podczas uroczystości rodzinnych lub lokalnych oraz we wszystkie postne dni [...] (Keselica / kysielnica / kysyłycia, 2018).

Wydawać się zatem może, że dawna słowiańska kisielica pozostała w kulturze łemkowskiej, co po raz kolejny dowodzi jej ogólnosłowiańskiego charakteru, skoro znane są historyczne i współczesne poświadczenia tego leksemu zarówno z języków wschodnich, jak i południowych oraz zachodnich (jest to współcześnie danie popularne również w Czechach (a i w języku staroczeskim znane, jak podaje F. Sławski, do czego jeszcze powrócę), skąd mogło powędrować na tereny wschodnich i południowych Niemiec oraz Austrii i w związku z tym mogło mieć na tych terenach charakter regionalny (co potwierdzają zresztą przytoczone już przeze mnie źródła. Paralelne okazuje się ponadto spożywanie tej potrawy przez niższe warstwy społeczne). Wydaje się zatem niemal pewne zapożyczenie przez język niemiecki ogólnosłowiańskiego wyrazu kisielica > niem. giselitz (z wariantami graficzno-fonetycznymi po procesie dyftongizacji: geysslitz, geislitz, geislaz, geislazn, geesliz), skąd z kolei wyraz został przejęty do staropolszczyzny jako giejślic:

kisielica > niem. giselitz > stpol. giejślic.

Giejślic zatem to w języku staropolskim pożyczka zwrotna z języka niemieckiego, który wcześniej przejął leksem kisielica z języków słowiańskich. Janusz Siatkowski zaznaczył w jednym ze swoich artykułów, że „już dosyć dawno zwrócono uwagę na elementy słowiańskie w niemieckim języku ogólnym, a zwłaszcza w gwarach i w języku potocznym regionów sąsiadujących z obszarem słowiańskim" (2015: 142). Właśnie ograniczenie terytorialne nazwy geislitz w języku niemieckim, ponadto również ograniczenie społeczne (potrawa spożywana głównie przez chłopów) mogą potwierdzać powyższą tezę. Dodatkowo w najstarszych niemieckich książkach kucharskich (o czym jeszcze szerzej niżej) nie odnajdujemy dokładnego przepisu na to danie ze względu na elitarność tychże wydawnictw z jednej strony i pospolitość tego rodzaju potrawy $z$ drugiej.

Co dotyczy dalej współczesnych użyć wyrazu: jeszcze niedawno, bo w 2019 roku, jeden z czołowych artykułów w „Gazecie Wyborczej” nosił tytuł: Kisielica i prosfora na stołach w prasłowiańskich domach. W menu restauracji Młyn w Ustrzykach Dolnych w Bieszczadach odnajdujemy również pozycję kisielica jako nazwę tradycyjnej potrawy bieszczadzkiej, żurku właśnie o specyficznym jednak smaku i sposobie przyrządzania.

O słowiańskim rodowodzie tego współczesnego również dania świadczy jeszcze kolejny zapis, mianowicie Ako jedli poddaní w języku słowackim. Czytamy tam:

Najbardziej rozpowszechniona i najbardziej znana owsianka ubogich, kyselica (również przygotowana jako zupa), która przetrwała do dziś. Posiłki spożywano również w Czechach, skąd 
rozprzestrzeniły się na przykład do Austrii (jedzenie nazywano tam „giselitze”) (https://www. sme.sk/c/206632/ako-jedli-poddani.html).

Z Czech potrawa ta powędrowała $\mathrm{z}$ kolei do Austrii i razem $\mathrm{z}$ desygnatem język niemiecki przejął też słowiańską formę wyrazu (zapożyczenie właściwe, leksykalne). Potwierdza to z kolei ponownie fakt, że była to potrawa spożywana przez ubogich: „najbardziej znana owsianka ubogich". Leksem ten znany był już w języku staroczeskim. W pracy Staročeské názvy jídel. Historicko-srovnávací studie Irena Blažkova pisze: „O wpływie kuchni czeskiej wśród Niemców świadczą chociażby słowa określane jako giselitze (zakwas), bochenz (z czeskiego bochnec) czy mosanze (mazaniec)" (2006: 26), zatem do Niemiec potrawa ta mogła zostać zapożyczona z kuchni czeskiej - należy więc doprecyzować: staroczeskiej. Potwierdzenie istnienia w języku staroczeskim leksemu kiselica odnajdujemy we wspomnianym już słowniku staroczeskim Jana Gebauera. Jak pisze Eva Juklová, staroczeska kysělicě (w nowszej czeszczyźnie kyselice) jest poświadczona w dziele Václava Flajšhansa z 1926 roku Klaret a jeho družina, który nawiązuje do napisanego przed 1348 roku poematu dydaktycznego Claretusa pt. Complexionarius, w części słownikowej leksem ten zatem był znany w Czechach już w XIV wieku. Wzmianki o tym daniu pojawiają się ponadto w najstarszym czeskim zbiorze rękopiśmiennych receptur z XV wieku oraz w słowniku z roku 1511 Lactifer latinsko-český Jana Bosáka Vodňanského zwanego Aquensis. Przepis na kisielicę odnajdujemy również w książce kucharskiej Bavora Rodovskégo z Hustiřan z roku 1591 - danie to było rodzajem gęstej zupy na bazie bulionu mięsnego, w tym przypadku na bazie mięsa z koguta, przypominającej gęstą owsiankę. XVI-wieczne czeskie przepisy podają również kisielicę ze szczupaka (to samo źródło), z pawia (ts.), kisielicę wieprzową lub cielęcą (najstarszy czeski zbiór przepisów kulinarnych z XV w.) (Juklová 2006: 29-30). Ta trzykrotna zatem, więc istotna - biorąc pod uwagę stan zachowania źródeł dokumentacja tego leksemu w języku czeskim w XV i XVI wieku, świadcząca prawdopodobnie o popularności tego dania w Czechach, może rzeczywiście dowodzić czeskich źródeł tego słowa i stąd zapożyczenia do języka niemieckiego. W innym ważnym czeskojęzycznym źródle, mianowicie Staročeské umění kuchařské Čeněka Zíbrta, autora, który zebrał setki przepisów z najstarszych czeskich książek kucharskich z XVI-XVII wieku, odnajdujemy dwa przepisy na kisielice - „Kyselice z vepřových, neb z telecích paznehtuov” oraz „Kyselice z liňóv”. Kisielica to $\mathrm{w}$ tych przepisach znów rodzaj gęstego żuru przygotowywanego na słodko na wywarze z mięsa, $\mathrm{z}$ dodatkiem miodu, często następnie przecedzanego przez durszlak, studzonego i krojonego, spożywanego na zimno w kawałkach.

W kolejnym źródle z języka czeskiego znajdujemy kisielicę jako tradycyjny poranny posiłek pracowników leśnych, bardzo obfity i sycący, spożywany głównie w miesiącach zimowych. W tym samym źródle czytamy, że potrawa znana była od dawna w Europie Północnej i Środkowej, a o jej popularności świadczy wiele jej odmian, również regionalnych. I dalej:

W Polsce żyto jest jej tradycyjnym składnikiem, w odmianie żur lub żurek, a gdy używa się pszenicy, nazywa się tę potrawę barszczem białym (https://www.196flavors.com/czech-republic-kyselica/), 
zatem podstawą kisielicy w Polsce było żyto, jej wariantami żur, żurek lub barszcz biały, gdy zamiast z żyta sporządzono tę potrawę z pszenicy. Co istotne, kisielica jest przez autorów uznawana właśnie za tradycyjne danie kuchni czeskiej, choć pochodzące według powszechnego przekonania z Rumunii z okresu między XIV a XVII w., a przeniesione zostało do Czech podczas emigracji rumuńskich pasterzy na tereny czeskie. Ta hipoteza wydaje się znów potwierdzać fakt, że kisielica była daniem niższych warstw społecznych, ale z kolei późny okres pochodzenia razem ze wskazaną w źródle powszechnością potrawy w Europie Środkowej i Północnej pozwalają obalić hipotezę o rumuńskiej genezie potrawy. W innym czeskojęzycznym źródle czytamy jeszcze:

Valašská Kyselica (Wołoski kapuśniak)

Kyselica to rodzaj czeskiego kapuśniaku, którego nie należy mylić z kyselo, czyli żurkiem. Przymiotnik Valašská oznacza, że pochodzi z tzw. Morawskiej Wołoszczyzny [...]. Od XIV wieku zza Karpat Południowych i Węgier zaczęli tu napływać emigranci z Wołoszczyzny. [...] Trudno jednak stwierdzić, na ile kyselica to ich oryginalny wkład do czeskiej kuchni [...]. Bardzo podobny przepis obowiązuje zresztą w Polsce (https://www.notatnikkuchenny.pl/valasska-kyselica-woloski-kapusniak/).

Współcześnie czeski żurek zatem nosi nazwę kyselo, zaś kisielica gotowana była na bazie kiszonej kapusty. Źródłosłów jest oczywiście ten sam: ${ }^{\star} k y s e l b$ według Wiesława Borysia prasłowiańskie dialektalne 'coś zakwaszonego, zwłaszcza potrawa z zakwaszonej mąki owsianej (w stpol. od XV w.); kisnać od pie. *kut-s od pie. kuat 'kisić, kwasić' (SEJP: 231). Jak dowodzi zatem Boryś, już na obszarze prasłowiańszczyzny leksem mógł mieć charakter ograniczony terytorialnie.

Powyższe rozważania wskazują po pierwsze na funkcjonowanie u Słowian leksemu kisielica (prasłowiańskiego i ogólnosłowiańskiego, co dokumentują ÈssÂ XIII: 269-270 oraz Etymological Dictionary of the Slavic Inherited Lexicon Ricka Derksena: s.v. ${ }^{*}$ kysati i pokrewne), przejętego z kolei przez język niemiecki; po drugie jego ograniczonego terytorialnie i społecznie zakresu użycia. Niewyjaśnione jednak zostaje do końca znaczenie leksemu kisielica / giejślic oznaczającego prawdopodobnie ‘żur', według różnych źródeł przygotowywany na bazie żyta bądź owsa, oraz jego zakres znaczeniowy wobec innych jednostek w staropolszczyźnie, takich jak żur i kisiel.

Badania Karla Rhamma, Milovana Gavazziego, Adama Maurizia i wreszcie Gerarda Labudy, zatem opracowania z zakresu historii kultury materialnej, potwierdzają istnienie odrębnych dań w Polsce średniowiecznej, mianowicie żuru, kisielu i kisielicy. Pozwalają stwierdzić, że kisiel, żur i giejślic to trzy różne potrawy Słowian.

K. Rhamm w przyczynku Talken und Geislitz (russisch toloknó und kisèlj), zwei alte slawische Hafergerichte uznał dwie nazwy kulinarne oznaczające kisiel sporządzony z owsa za z pochodzenia ruskie (podobnie J. Rostafiński (1900: 499) uznał nazwę kisiel za ruską z brzmienia i pochodzenia). Odróżnił ponadto kisiel szlachecki (z dodatkiem miodu) od chłopskiego, zaś określenia funkcjonujące na terenie Niemiec wywodziły się według autora z języka Słowian zamieszkujących od prastarych czasów wschodnie zbocza Alp. Autor zrównuje niemieckie geislitz ze słowiańskim kisiel. M. Gavazzi uznał nazwę kisiel za wywodzącą się jeszcze z czasów 
wspólnoty słowiańskiej. Nawiązując do ich rozważań, Gerard Labuda wyraźnie odróżnił rzeczowo dwie potrawy kisiel i kisielicę (od niej niem. geislitz), choć obie pochodzące z owsa. „Kisielicę, podobnie jak tłokno, rozpowszechnione u zgermanizowanych Słowian alpejskich, przyrządzano z krup owsianych, kisiel natomiast, jak wiadomo, robi się z mąki owsianej" (Labuda 1956: 152). Tymczasem przekaz wspomnianego Nestora podaje, że do przyrządzenia kisielu użyto "garści owsa lub pszenicy, lub otrębów”, zatem nie wyłącznie owsa. M. Gavazzi, powołując się na obfity materiał etnograficzny z terenu całej Słowiańszczyzny, uznaje owies za podstawę kisielu. „Wydaje się jednak, że zachodziła tu jakaś ewolucja późniejsza, gdyż na przykład na Ukrainie kisiel lub kisielica była przyrządzana z mąki kukurydzianej, prosianej, rżanej, jęczmiennej i także owsianej. Trzeba by zbadać, w jakim kierunku szła ewolucja: od owsa do innych gatunków zbóż czy też odwrotnie" (Labuda 1956: 152). G. Labuda podkreśla dodatkowo znamienny fakt, że u Słowian południowych nie zachowała się nazwa kisielu w żywej mowie jako nazwa potrawy. Jednakowoż zarówno badania K. Rhamma, M. Gavazziego, jak i G. Labudy wykazują wspólnosłowiańską podstawę nazw kisiel i kisielica (giejślic), „,co pozwala przesunąć wprowadzenie tej potrawy jeszcze do prastarych czasów” (Labuda 1956: 152).

A. Maurizio w pracy Pożywienie roślinne i rolnictwo w rozwoju dziejowym z kolei odróżnia tylko kisiel od żuru, z tym drugim utożsamia natomiast giejślic. Nie podaje w ogóle nazwy kisielica. Kisiel według autora znany jest pod tą nazwą w całej Rosji (czym autor potwierdza tezę J. Rostafińskiego o ruskim pochodzeniu słowa), a „prawdopodobnie również u wszystkich ludów północnej Europy. Pierwotnie robiono go z owsa, wreszcie z ziemniaków" (Maurizio 1926: 140). Autor, powołując się na przepis Alexandra Treichela, podaje sposób na przygotowanie kisielu, polegający na tym, że na zmiażdżony lub mielony owies wlewa się ciepłą wodę, następnie dodaje się zakwasu z chleba i tak przygotowany wywar poddaje kiszeniu. Po tymże całość się odcedza. Często w ramach oszczędności przenosi się zakwas z jednego kiszenia na następne, a nawet ten sam kisiel kwasi kilka razy po dodaniu do starego odrobiny świeżej mąki i dużej ilości wody (Maurizio 1926: 140). W tym kontekście łatwo wytłumaczyć pochodzenie frazeologizmu dziesiąa woda po kisielu ${ }^{7}$, skoro ten sam kisiel, ale rozrzedzony, gotuje się kilkakrotnie. Nazwa kisiel występuje już dziś w polszczyźnie ogólnej wyłącznie w znaczeniu 'półpłynnego, słodkiego deseru z mąki ziemniaczanej, soku owocowego, wody i cukru'

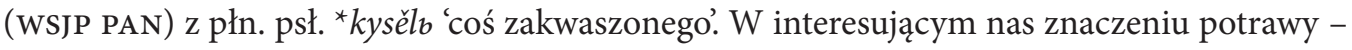
rodzaju zupy - występuje w słownikach: sstp, SPXVI, Cn, L (notacje z wieków XVII i XVIII), ESXVII, SW 'rodzaj kwaśnej rzadkiej potrawy z mąki owsianej', natomiast już w SJPDor wyłącznie w dzisiejszym znaczeniu słodkiej potrawy z dodatkiem owoców. W SGP PANKart odnajdujemy następujące znaczenia słowa kisiel: 'kisiel z mąki owsianej na wywarze z suszonych owoców', 'gęsta potrawa z mąki gryczanej, kukurydzianej lub żytniej, rzucanej na wrzącą wodę,' 'postna potrawa $\mathrm{z}$ mąki owsianej', także w znaczeniu 'żur'. Zachowane jest też w słownictwie kresowym jako 'rodzaj gęstego żuru; kwaśna polewka z mąki owsianej. Irena Łukaszuk odnajduje leksem kisiel wśród rosyjskich nazw potraw, podkreślając, że jest to wyraz ogólnosłowiański, oznaczający potrawę bardzo starą. Wyraz ten notuje również W. Dal w języku białoruskim, 
wymienia ponadto różne rodzaje kisielu: owsiany, rżany, pszeniczny, grochowy, z prosa (Dal' 1880-1882 II: 110). Leksemu kisiel w dawnym znaczeniu nie odnajdujemy w językach południowosłowiańskich, zachowały go natomiast języki wschodniosłowiańskie.

Jak wynika zatem z dotychczasowych rozważań, wydaje się prawdopodobne, że Słowiańszczyzna znała trzy różne, choć zbliżone potrawy: kisiel, kisielicę i żur, choć w innym jeszcze źródle, mianowicie Andreja Pleterskiego Das Brot ist Lebensquelle. Nichts darf übrig bleiben czytamy o kisielicy:

kisielica - mieszanka wody i mąki owsianej, która stoi do zakwaszenia, również przy pomocy drożdży. Mąkę, otręby, kaszę mannę czy płatki zbożowe z ziaren pszenicy - często również owsa lub jęczmienia - zalewany wrzącą wodą. Często dodajemy kawałek drożdży lub skórkę startego chleba (zakwas). Odstawiamy do ciepłego miejsca, aby sfermentowało. Następnie płyn jest zwykle odcedzany, a jedzenie spożywane na ciepło lub na zimno (2015: 127).

Autor podkreśla, że procedura wytwarzania kisielicy i jej nazwa są w krajach słowiańskich powszechne, dlatego można je zaliczyć do kultury kuchennej słowiańskiego „pierwotnego domu", występuje we wczesnym średniowieczu. Oczywiście kisielica podlegała na terenie Słowiańszczyzny różnym modyfikacjom. Tak na przykład u Chorwatów w Bačce była to kiselica lub kwašenica - zupa na kwaśnym mleku i chlebie przygotowywana na pamiątkę Wielkiego Piątku w piątki; u Czechów kyselo wytwarzane z drożdży; w języku morawskim kyselica, zelnica lub zelnačka, w języku rosyjskim kisel, w Polsce średniowiecznej kyssel - danie z jęczmienia. Według tego autora kisielica była w Polsce przygotowywana tylko w okresie Wielkiego Postu, doprawiana szczególnie solą i czosnkiem. Pod koniec Wielkiego Postu garnek gliniany, w którym przygotowywano kisielicę, symbolicznie rozbijano i zakopywano w ziemi (por. Pleterski 2015: 127-128). Na podstawie tych rozważań można przypuszczać, że pierwotna wspólnosłowiańska kisielica stała się później dopiero podstawą do regionalnych czy raczej jej narodowych wariantów, jak żur, kisiel, giejślic, kwaszenina czy kyselo. Należy zatem w tym miejscu stwierdzić, że skoro potrawa ta występowała w tak wielu odmianach, w niektórych regionach mogła być synonimem żuru (potrawy przecież kwaśnej i pojawiającej się również w wielu odmianach) i kisielu (z tych samych względów).

Nie sposób jeszcze nie odnieść się do zasadniczego w tym względzie źródła, mianowicie do receptur kulinarnych polskich i niemieckich. W przepisach polskich nie odnajdujemy niestety receptury na giejślic, natomiast w niemieckich, nawet najstarszych, owszem.

Najstarsza książka kucharska opublikowana w języku niemieckim - Küchenmeisterei pochodzi z 1485 roku i jest dziełem anonimowego autora. Dużo miejsca w tej książce „poświęca się daniom mącznym oraz tak zwanym brejom (niem. Müß) z migdałów, ryb i mięsa" (Sikorska 2019: 28). Nie odnajdujemy w niej niestety przepisu na giejślic. Pojawia się on natomiast w drugiej niemieckiej książce kucharskiej - Ein künstlichs und nutzlichs Kochbuch Balthasara Staindla z 1569 roku w dziale dziewiątym Suppen. Giejślic wymieniany jest jako nazwa ryby, gotowanej i spożywanej po ostygnięciu i po zdjęciu z niej kożucha wytwarzającego się właśnie podczas zsiadania potrawy. Nie wynika jasno ze źródeł niemieckich, skąd ryba wzięła taką nazwę, choć można przypuszczać, że ze względu na formę, konsystencję, w jakiej ją spożywano. Wydaje się 
potwierdzać takie przypuszczenie późniejsza już znacznie niemiecka książka kucharska Hansa von Wirtenberga z 1844 roku, znana przede wszystkim z przedruku z 1851 roku Kochbuch von maister Hannsen des von Wirtenberg koch, w której czytamy, że giejślic to średnia, mało popularna ryba ze względu na jej niesmaczne mięso, łowiona przez rybaków w Mierzei Gdańskiej, znana w ogóle w prowincji pruskiej. Gotuje się ją w słonej wodzie, a następnie spożywa z octem (mięso tłuste, splecione). Te uwagi sugerują, że ryba ta była podawana na kwaśno, stąd prawdopodobnie jej nazwa. Takie znaczenie wyrazu odnajdujemy również w opracowaniu Johanna Gottlieba Bujacka Naturgeschichte der höheren Thiere, wydanym w Königsbergu w 1837 roku: „Łowi się ją niedaleko Gdańska w Prusach Wschodnich, znana jest w większości prowincji Niemiec" (1837: 394). Gotuje się ją lub smaży z octem i oliwą lub je się z bulionem musztardowym z kaparów i wina.

To tłumaczenie wyrazu giejślic prowadzi nas zatem do konsystencji pokarmu spożywanego w postaci miazgi lub galaretowatej masy. Wydaje się, że to znaczenie, znane już w języku niemieckim w XV wieku, mogło jednocześnie opisywać konsystencję żuru bądź kisielu. Potwierdza to zresztą Deutsches Wörterbuch Jacoba i Wilhelma Grimmów, który notuje kilka znaczeń wyrazu giejślic:

1. W XV w. forma prezentacji w postaci miazgi lub galaretowatej, znana jeszcze w XVII w.; 2. mhd. w XII wieku glicerium, giseliz jako pyszna potrawa (por. Liquericium u. B)., z drugiej strony jako danie wiejskie w XIII wieku, rodzaj owsianki spożywanej przez chłopów (w niemieckim poemacie Meier Helmbrecht), w Wiener Kochbuch jest to jednak bardziej wyszukane danie z migdałami lub winogronami i piernikiem. (Należy w tym miejscu podkreślić, że w tym znaczeniu wyraz znany był już w XII w. Odnajdujemy go w wiedeńskim rękopisie z XII w., w którym objaśnia się giejślic porównaniem do polenty, dania bardzo popularnego w Wiedniu. Była to potrawa w stylu polenty, tylko z innych drobniejszych materiałów, którą pozostawia się do ostygnięcia, a potem się ją kroi. Właśnie taką recepturę podaje wspomniana najstarsza niemiecka książka kucharska8); 3. mowa bawarsko-austriacka: owsianka z owsa, smakuje kwaśno i na zimno; 4. w Karyntii geisliz, geislaz m., geislazn f. zrobiony z owsa, najpierw gotowany, następnie suszony i mielony. To w zasadzie kasza, kasza owsiana od rolników (czyli jako żywność, gotowana), pojawia się na eleganckich stołach na północy w języku duńskim; 5. godna uwagi jako forma zależna „sorbicium gairschlicze”, rodzaj sorbetu (łacińskie słowo oznacza też zupę); 6. mus z gotowanych owoców, ros. kisely 'kwaśny kleik, owsianka' kissělus; kys w bohem. kysati, 'ferment, kwaśny, fermentacja, która wytwarza kwas', pierwiastek obecny w niem. Geislitze.

Co ciekawe, w słowniku tym odnajdujemy przypuszczenie, że ta pożyczka od Słowian, znana już w XII i XIII wieku, ugruntowała się prawdopodobnie z Czech, częściowo jako wyśmienita lub orzeźwiająca potrawa, częściowo jako danie wiejskie.

8 Powyższe wiadomo ze źródła: https://archive.org/details/bub_gb_vaoVAAAAIAAJ/page/n305/mode/2up?q=giseliz Sitzungsberichte der Kaiserlichen Akademie der Wissenschaften, Philosophisch-Historische Klasse By Kaiserl. Akademie der Wissenschaften in Wien. Philosophisch-Historische Klasse, dostęp: 3 czerwca 2018). 
Szukając materiałów w najstarszych niemieckich książkach kucharskich, odnalazłam jeszcze nowe znaczenie leksemu giejślic, nienotowane w powyższym źródle, a pochodzące z przepisu z Alte Kochrezepte aus dem bayrischen (Niemcy, ok. 1500 - V. Bach, tłum.), zatytułowanego Raiger in a geislicz:

/ Raiger / (czapla?) W / geislicz / (sos?). Najpierw ugotuj. Następnie weź mięso i funt migdałów i zmiel je razem (Danner (red.), Kochrezepte — Institut für Germanistik (uni-giessen.de)).

Odnalazłam ponadto takie znaczenie wyrazu giejślic w niemieckim korpusie tekstów średniowiecznych, kulinarnych, w rękopisie Ka 2: Karlsruhe, Badische Landesbibliothek, Donaueschingen 793, folio: 95r, wydanie: Danner 1970, numer przepisu: $29^{9}$.

Z powyższych danych wynika, że giejślic był również rodzajem sosu dodawanego do mięs ${ }^{10}$; wydaje się, że ów sos był również kwaśny.

Hasło giejślic odnajdujemy w opracowaniu Tirol és Vorarlberg német tájszólásai Hintnera Bálinttóla.

Okazuje się, że słowo to znane jest również w języku węgierskim: geilitze (giselitze środkowogórskie, geyslitz, kisel słowiański, słowo kwaśne), żurek na czczo zwany po węgiersku kiszőcze. Należy przypuszczać, że zostało przejęte przez język węgierski właśnie z południowych dialektów języka niemieckiego, a to może potwierdzać z kolei popularność tego dania w kuchni chłopskiej.

Na podstawie powyższych ustaleń można sformułować hipotezę o zmianach semantycznych, jakie przechodził słowiański z pochodzenia, niemiecki leksem geislitz (z wariantami graficzno-fonetycznymi). Zmiany te w pierwszym rzędzie mogły polegać na generalizacji znaczenia, tj. od słowiańskiej kisielicy - dania o specyficznej, dość gęstej konsystencji, ograniczonego terytorialnie do południowych dialektów języka niemieckiego (Niemiec i Austrii), do znaczenia szerszego: konsystencji galaretowatej masy, miazgi; następnie na specjalizacji znaczeniowej w dwóch kierunkach: 1. sosu do potraw mięsnych; 2. ryby spożywanej w takiej formie. Wszystkie zebrane tu dane dowodzą z pewnością wysokiej frekwencji użycia leksemu w języku niemieckim, tak w rezultacie wieloznacznego. Wobec tej refleksji wyjątkowo zadziwiająca jest z kolei niewielka w zasadzie znajomość leksemu giejślic / kisielica w języku polskim.

\section{Podsumowanie}

W świetle zebranych w niniejszym artykule danych filologicznych, językoznawczych, etnograficznych i gospodarczych można sformułować - choć ostrożnie, bo jak każde ustalenia historycznojęzykowe, w dużej mierze hipotetyczne, tak i te wymagają dalszych analiz - pewne wnioski szczegółowe:

\footnotetext{
9 W: Portal roślin średniowiecza / Medieval Plant Survey, wydawca: Helmut W. Klug, kierownictwo techniczne: Roman Weinberger. 2009-2020 (online: http://medieval-plants.org/mps-daten/recipe/reiher-in-einer-geislicz-karlsruhe-badischelandesbibliothek-donaueschingen-793/; dostęp: 26 listopada 2020).

$10 \mathrm{~W}$ przepisach z Bawarii jako sos z XV w. (http://www.eg.bucknell.edu/ lwittie/sca/food/Inntal\%20-\%20Bavaria\%2O late\%2015th.pdf, dostęp: nn nnnnnnn nnnn).
} 
1. W języku staropolskim występował prawdopodobnie leksem kisielica, nienotowany w żadnym z zachowanych źródeł, zatem i nienotowany w sstp.

2. Leksem ten miał charakter ogólnosłowiański, czego dowodzą słowniki etymologiczne (por. Èss Â; Derksen 2008) oraz zachowane do dziś formy w językach: polskim (w języku mieszkańców południowo-wschodnich i południowo-zachodnich obszarów Polski, tj. Dolnego Śląska i Podkarpacia), czeskim, słowackim, w językach ruskich, serbskim i chorwackim.

3. Oznaczał potrawę spożywaną częściej przez niższe warstwy społeczne, przyrządzaną na bazie żyta lub - co bardziej prawdopodobne - owsa. Zboża te zakwaszano, bowiem istotą potrawy był jej kwaśny smak.

4. Język staropolski odróżniał zatem trzy leksemy: żur, kisiel i kisielica, oznaczały one jednak różne potrawy, choć zbliżone.

5. Słowianie przenieśli leksem kisielica do języka niemieckiego (zwłaszcza Słowianie alpejscy), być może z Czech wyraz ten powędrował razem z potrawą do Austrii (zwłaszcza Karyntii i Tyrolu) i Niemiec, co potwierdza słownik braci Grimmów.

6. Niemcy przejęli leksem słowiański z jego formą i znaczeniem (zapożyczenie właściwe, leksykalne giselitz z późniejszymi wariantami graficzno-fonetycznymi, powstałymi po procesie dyftongizacji: geislitze, geysslitz, geislitz, geislaz, geislazn, geesliz) i proces ten musiał przebiegać bardzo dawno, bo najwcześniejsze poświadczenie leksemu pochodzi z XII, a może i z X wieku.

7. Wyraz ten miał jednak w języku niemieckim ograniczony zasięg terytorialny (dialekty południowe) i społeczny (niższe warstwy społeczne, chłopi).

8. Ulegał jednak w języku niemieckim zmianom semantycznym (generalizacji i specjalizacji), czego efektem była już w XVI wieku wieloznaczność tego leksemu.

9. Formę niemiecką geislitz przejął niejako „z powrotem” język polski i sstp notuje wyraz giejślic.

10. Powyższe rozważania doprowadziły ponadto do źródeł frazeologizmu dziesiąta woda po kisielu (z różnymi wariantami, m.in. siódma woda o kisielu): często w ramach oszczędności przenoszono zakwas z jednego kiszenia na następne, a nawet ten sam kisiel kwaszono kilka razy po dodaniu do starego odrobiny świeżej mąki i dużej ilości wody; tę wodę / rozrzedzony kisiel gotowano kilkakrotnie.

11. Ogólnosłowiański zatem wyraz kisielica dołącza do derywatów od czasownika

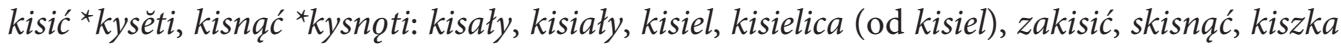
(psł. * kyšs ka 'coś skwaśniałego') itd. i dowodzi innowacji dialektalnych prasłowiańskich osnów i centrów, tu centrum werbalnego.

12. Jeśli chodzi o derywację, wyraz fundowany kisielica od fundującego kisiel może uchodzić za typ derywacji udowodniony już w oparciu o materiał staropolski, mianowicie derywacji synonimicznej względem podstaw słowotwórczych czy derywacji tautologicznej. Temu problemowi poświęciła już sporo uwagi Krystyna Kleszczowa (1998: 36-45). Autorka wymieniła zresztą sufiks -ica w tej grupie derywatów, o innej jednak wartości funkcjonalnej. 


\section{Bibliografia}

Ako jedli poddaní, „Životný Štýl” 2002 (online: https://www.sme.sk/c/206632/ako-jedli-poddani.html, dostęp: 23 listopada 2020).

Bálinttól H.: Tirol és Vorarlberg német tájszólásai (online: https://www.arcanum.com/hu/online-kiadvanyok/OMMonarchia-az-osztrak-magyar-monarchia-irasban-es-kepben-1/tirol-es-vorarlberg-1D2D/tirol-es-vorarlberg-nepe-1F31/tirol-es-vorarlberg-nemet-tajszolasai-hintner-balinttol-forditotta-katona-lajos-1FFE/, dostęp: 15 lutego 2021).

Blažkova I. 2006: Staročeské názvy jídel. Historicko-srovnávacístudie, Brno (online: https://view.officeapps.live.com/op/view. aspx?src=https\%3A\%2F\%2Fis.muni.cz\%2Fth\%2F155755\%2Fff_m\%2Fcelek.doc\&wdOrigin=BROWSELINK, dostęp: 15 lutego 2021).

Bujack J.G. 1837: Naturgeschichte der höheren Thiere: mit besonderer Berücksichtigung der Fauna Prussica. Ein Handbuch für Lehrer der Jugend, Oekonomen, angehende Forstmänner und Freunde der Natur, Mit 2 Kupfertafeln, Gräfe u. Unzer, Königsberg.

Cn: Knapiusz G. (Knapski; Gregorius Cnapius), Thesaurus polono-latino-graecus seu promptuarium lingua Latinae et Graecae [...], F. Caesario, Cracoviae [Kraków] 1621.

Czarnecki T. 2014: Die deutschen Lehnwörter im Polnischen. Untersuchungen zur Chronologie und Geographie der Entlehnungen, Wydawnictwo Naukowe Instytutu Kulturologii i Lingwistyki Antropocentrycznej Uniwersytetu Warszawskiego, Warszawa.

Dal' V.I. 188o-1882: Tolkovyj slovar' živogo velikorusskogo âzyka, t. 1-4, Russkij âzyk, Moskva.

Derksen R. 2008: Etymological Dictionary of the Slavic Inherited Lexicon, Leiden-Cambridge University Press, Boston.

̇̀ssÂ: Ėtimologičeskij slovar' slavânskih âzykov. Praslavânskij leksičeskij fond, t. 1-41, red. O. Trubačëv i in., Nauka, Moskva 1974-2018.

ESXVII: Elektroniczny słownik języka polskiego XVII i XVIII wieku, red. W. Gruszczyński (online: http://sxvii.pl, dostęp: 15 maja 2018).

Flajšhans V. 1926: Klaret a jeho družina. Sv. I: Slovníky veršované. Text z rukopisů upravil a vydal V. Flajšhans, Nákladem České akademie věd a umění, Praha.

Gavazzi M. 1954: Beiträge zur altslavischen Kulturkunde, „Zeitschrift für Slavische Philologie”, vol. 22, no. 2, s. 395-415.

Gebauer J. 1903-1916: Slovník staročeský, t. 1-2, Academia, Praha.

Grimm J.W. 1854-1961: Deutsches Wörterbuch, Verlag von S. Hirzel, Leipzig.

Hornung M. 1964: Mundartkunde Osttirols/ Eine dialektgeographische Darstellung mit volkskundlichen Einblicken in die altbäuerliche Lebenwelt - mit laut- und wortkundlichen Karten, H. Böhlaus Nachf., Kommissions-verlag der Österreichischen Akademie der Wissenchaften, Graz.

Juklová E. 2006: Některé názvy jídel ve staré češtině. Pưvod a vývoj, Brno (online: https://theses.cz/id/a4wdkn/?lang=sk, dostęp: 15 lutego 2021).

Jungmann J. 1836: Slovník česko-německý, Díl II., K-O, Academia, Praha.

Keselica / kysielnica / kysyłycia, Ministerstwo Rolnictwa i Rozwoju Wsi, 3 czerwca 2018 (online: https://www.gov.pl/web/ rolnictwo/keselica-kysielnica-kysylycia; dostęp: 28 listopada 2020).

Kisielica i prosfora na stołach w prasłowiańskich domach, „Gazeta Wyborcza” 6 stycznia 2019 (online: https://gorzow.wyborcza.pl/ gorzow/7,36844,24333988,kisielica-i-prosfora-na-stolach-w-prawoslawnych-domach.html, dostęp: 4 grudnia 2020).

Kleszczowa K. 1998: Staropolskie kategorie słowotwórcze i ich perspektywiczna ewolucja. Rzeczowniki, Wydawnictwo Uniwersytetu Śląskiego, Katowice.

Kolberg O. 1974: Dzieła wszystkie, t. 49: Sanockie-Krośnieńskie, Polskie Wydawnictwa Muzyczne, Wrocław-Poznań.

Koutna K., Kyselica (online: https://www.196flavors.com/czech-republic-kyselica/, dostęp: 21 stycznia 2021).

Kowalik-Kaleta Z., Dacewicz L., Raszewska-Żurek B. 2007: Słownik najstarszych nazwisk polskich - pochodzenie językowe nazwisk omówionych w „Historii nazwisk polskich. T. 1.”, Slawistyczny Ośrodek Wydawniczy, Warszawa.

Kremer A. 1870: Słowniczek prowincjonalizmów podolskich ułożony w Kamieńcu Podolskim w r. 1863, „Rocznik ces.-król. Towarzystwa Naukowego Krakowskiego", s. 178-259.

L: Linde S.B. 1807-1814: Słownik języka polskiego, t. 1-6, Drukarnia Xx. Pijarów, Warszawa.

Labuda G. 1956: M. Gavazzi, „Beiträge zur altslavischen Kulturkunde”, „Zeitschrift für Slavische Philologie” Vol. 22, No. 2, s. 395415; „Kwartalnik Historii Kultury Materialnej”, t. 4, s. 152.

Lexer M. 1872: Mittelhochdeutsches Handwörterbuch, t. 1, Verlag von S. Hirzel, Leipzig. 
Łukaszuk I. 2005: Rosyjskie nazwy kulinariów na tle języków słowiańskich, Wydawnictwo Uniwersytetu w Białymstoku, Białystok.

Maurizio A. 1926: Pożywienie roślinne i rolnictwo w rozwoju dziejowym, Krośnieńska Oficyna Wydawnicza, Warszawa.

Menu restauracji „Młyn” w Ustrzykach Dolnych w Bieszczadach (online: mlynbieszczady.pl, dostęp: 16 stycznia 2020).

Nazwiska polskie: Kisielica (online: https://nazwiska-polskie.pl/Kisielica, dostęp: 27 grudnia 2020).

Parylak P. 1877: Prowincyjonalizmy mowy polskiej w Drohobyczu i jego okolicach zestawione i porównane z językiem ruskim, staropolskim i narzeczem kaszubskim, „Zbiór Wiadomości do Antropologii Krajowej”, t. 1, s. 57-79.

Pleterski A. 2015: Das Brot ist Lebensquelle. Nichts darf übrig bleiben (Bread is a Source of Life. Nothing Must be Left), [w:] H. Kenzler, H. Losert (red.), Die Rekonstruktion mittelalterlicher Lebenswelten (The Reconstruction of Medieval Lifeworlds). Ein Kolloquium zum 6o. Geburtstag von Ingolf Ericsson, Bd. 2, Verlag der Buchhandlung Eckhard Bodner, Pressaths, s. 123-142.

Pohl H.D. 2005: Deutsch-slowenische und slowenisch-deutsche Lehnbeziehungen als Spiegel der Kulturgeschichte (gezeigt an Speisenbezeichnungen), [w:] I. Hausner, Wiesinger P. (red.), Deutsche Wortforschung als Kulturgeschichte. Beiträge des Internationalen Symposiums aus Anlass des 9o-jährigen Bestandes der Wörterbuchkanzlei der Österreichischen Akademie der Wissenschaften, Wien, 25. - 27. September 2003, ÖAW, Wien, s. 287-311.

Pohl H.D. 2019: Deutsch-slowenische Wechselbeziehungen in der Sprache der traditionellen Kärtner Küche, „Linguistica”, vol. 59(1), s. 253-265.

Rhamm K. 1909: Talken und Geislitz (russisch toloknó und kisèlj), zwei slavische Hafergerichte, „Carinthia”, vol. 1(99), s. $209-222$.

Rostafiński J. 1900: Symbola ad historiam naturalem medii aevi = Średniowieczna historya naturalna $w$ Polsce, cz. 1, Universitas Jagellonica, Cracoviae.

Rymut K. 1991: Nazwiska Polaków: słownik historyczno-etymologiczny, Wydawnictwo Instytutu Języka Polskiego PAN, Wrocław.

Schultz A. 2011: Essen und Trinken im Mittelalter (1000-1300): Literarische, kunsthistorische und archäologische Quellen, De Gruyter, Berlin/Boston.

SEJP: W. Boryś, Słownik etymologiczny języka polskiego, Wydawnictwo Literackie, Kraków 2010.

SESł: F. Sławski, Słownik etymologiczny języka polskiego, t. 1-5, nakł. Towarzystwa Miłośników Języka Polskiego, Kraków 1952-1982.

SGP PANKart: kartoteka Słownika gwar polskich (online: http://rcin.org.pl/dlibra/).

Siatkowski J. 2015: Historia badań nad wpływami słowiańskimi na język niemiecki, „Gwary Dziś”, nr 7, s. 141-154.

Sikorska M. 2019: Smak i tożsamość. Polska i niemiecka literatura kulinarna w XVII w., Uniwersytet Mikołaja Kopernika w Toruniu. Wydział Nauk Historycznych, Toruń

SJPDor: Słownik języka polskiego, red. W. Doroszewski, t. 1-11, Państwowe Wydawnictwo Naukowe, Warszawa $1958-1969$.

SPJs: Słownik pojęciowy języka staropolskiego, kier. projektu B. Sieradzka-Baziur, Insytut Języka Polskiego Polskiej Akademii Nauk, Kraków (online: https://spjs.ijp.pan.pl/szukaj/index).

SPXVI: Słownik polszczyzny XVI wieku, red. M.R. Mayenowa (t. 1-34), K. Mrowcewicz (t. 35-38), t. 1-22, Zakład Narodowy im. Ossolińskich, Wydawnictwo Polskiej Akademii Nauk, Wrocław-Warszawa-Kraków 1966-1994, t. 23-38, Instytut Badań Literackich Polskiej Akademii Nauk, Warszawa 1995-2020.

SPXVIKart: kartoteka Słownika polszczyzny XVI w. (online: https://rcin.org.pl/ijp/dlibra/publication/23912/edition/ 9030? language $=\mathrm{pl}$ )

sstp: Słownik staropolski, red. S. Urbańczyk, t. 1-9, Zakład Narodowy im. Ossolińskich, Wydawnictwo Polskiej Akademii Nauk, Wrocław-Warszawa-Kraków 1953-1987, t. 10-11, Instytut Języka Polskiego Polskiej Akademii Nauk, Kraków 1988-2002.

sstpKart: kartoteka Słownika staropolskiego (online: http://rcin.org.pl/dlibra/).

Staindl B. 1569: Ein künstlichs nutzlichs Kochbuch, Otmar, Augsburg.

sw: Słownik języka polskiego, red. J. Karłowicz, A. Kryński, W. Niedźwiedzki, nakładem prenumeratorów i Kasy im. Mianowskiego, Warszawa 1900-1927.

Unterforcher A. 1899: Die Namen des Kalserthales, „Veröffentlichungen des Tiroler Landesmuseums Ferdinandeum”, vol. 3(43), s. 19-68.

Urbańczyk S. 1963: Charakterystyka staropolskich zapożyczeń wyrazowych z języka ukraińskiego, [w:] T. Milewski, J. Safarewicz, F. Sławski (red.), Studia linguistica in honorem Thoddaei Lehr-Spławiński, Państwowe Wydawnictwo Naukowe, Warszawa, s. 437-445. 
Valašská kyselica (Wołoski kapuśniak) (online: https://www.notatnikkuchenny.pl/valasska-kyselica-woloski-kapusniak/, dostęp: 21 stycznia 2021).

Wackernagel W. 1853: Kochbuch von maister Hannsen des von Wirtenberg koch, „Zeitschrift für deutsches Alterthum”, vol. 9, S. $365-373$.

WSJP PAN: Wielki słownik języka polskiego PAN, red. P. Żmigrodzki (online: www.wsjp.pl, dostęp: 15 maja 2018).

Zíbrt Č. 1927: Staročeské umění kuchařské, Dauphin, Praha.

Summary

\section{About a mysterious old Polish dish - giejślic (siódma woda po kisielu 'the seventh water after jelly'?)}

Keywords: language history, etymology, Old Polish language, culinary names.

The article is a lexicological study of an Old Polish dish giejślic, an entry listed in Stownik staropolski with the comment in the dictionary file: "The word may be German". The author, referring mainly to German linguistic and historical-cultural literature (there are generally no Polish-language studies on this subject), tries to answer three basic questions: what was giejślic, is this word really a Germanism, what is in general its etymology and whether giejślic, sour soup and jelly are identical dishes. The result of this linguistic and historical search is probably the all-Slavic, and later also the Old Polish unit kisielica, not listed in Stownik staropolski, and borrowed by the Germans in the form of the geislitze lexeme with graphic and phonetic variants: geysslitz, giselitz, geislitz, geislaz, geislazn, geesliz, adopted by Polish later on in the form of the lexeme giejślic, yet meaning a dish slightly different than sour soup and jelly. The source of the idiomatic expression 'the seventh water after jelly' is not - as many sources claim - the slops in a jelly dish, but the fact that the jelly was boiled several times, adding water to the old leaven, so the jelly was thinned several times. 